\title{
IMPLEMENTASI PROGRAM KOMUNITAS BACA TULIS (KOBATU) SMK NEGERI 2 TEGAL DI MASA PANDEMI
}

\author{
Fauziah \\ Pascasarjana Universitas Negeri Semarang \\ e-mail: poyafauziah3@gmail.com
}

\begin{abstract}
ABSTRAK
Tujuan dari penelitian ini adalah sebagai berikut. (1) Mendeskripsikan bagaimana implementasi program kobatu untuk meningkatkan kompetensi peserta didik dalam menulis dan membaca karya sastra. (2) Mendeskripsikan bagaimana hasil dan dampak yang dicapai pasca implementasi program kobatu. (3) Mendekripsikan kendala apa saja yang terjadi pada pengimplementasian program kobatu. (4) Mendeskripsikan faktor apa saja yang mendukung pelaksanaan implementasi program kobatu. Teknik pengumpulan data dalam penelian ini menggunakan metode observasi, wawancara, dan kajian pustaka. Sedangkan teknik analisis data menggunakan metode analisis deskriptif kualitatif. Hasil penelitian menunjukkan, implementasi program kobatu untuk meningkatkan kompetensi peserta didik dalam menulis dan membaca karya sastra antara lain dengan perekrutan anggota, latihan atau sharing, dan launching produk. Hasil dan dampak yang dicapai pasca implementasi program kobatu antara lain peserta didik yang tergabung dalam anggota komunitas semakin meningkat kompetensinya dalam mencipta karya sastra yang diwujudkan dalam produk berupa antologi. Hal ini juga semakin membuat peserta didik lebih percaya diri. Selain itu, Kobatu dapat menjadi program unggulan sekolah dan diakui secara resmi oleh Perpusnas RI. Kendala yang terjadi pada pengimplementasian program kobatu tidak terlalu berarti, hanya masalah waktu latihan yang terbatas dan pemahaman peserta didik yang tidak sama. Faktor yang mendukung pelaksanaan implementasi program kobatu antara lain dari pihak sekolah, peserta didik, dan guru.
\end{abstract}

Kata kunci: komunitas baca tulis, kompetensi, puisi, cerpen.

\begin{abstract}
The purpose of this research is (1) Describing about implementation of the Kobatu programs to improve the competence of students in writing and reading literary. (2) Describing the results and impacts after the implementation of the Kobatu programs applied. (3) Describing the obstacles that occur in the implementation of the Kobatu programs. (4) Describing supporting factors about implementation of the Kobatu programs. The data collection technique using observasion method, interview, and literature review. In other side, the data analysis technique using qualitative descriptive analysis method. The results showed that the implementation of the Kobatu programs to improve students competence in writing and reading literary works, among others, was by recruiting members, training or sharing, and launching products. The results and impact after the implementation of the Kobatu programs aplied is the students who are join in community have the increase competency for creating literary. The competency is proven with anthology products. This fact, making students more confidence. In other side, Kobatu programs can be the best program in this school. And more important, this program is certified by Perpusnas RI. Even so, there are many obstacles, like the limited practice and unsyncronic understanding in students, but the obstacle will be fine along the time.. So need the supporting from many side like institutions, students and teacher for successing the Kobatu Programs.
\end{abstract}

Keywords: reading and writing company, competence, poetry, short story.

\section{PENDAHULUAN}

Mata pelajaran Bahasa Indonesia dalam Kurikulum 2013 memuat kompetensi dasar supaya peserta didik dapat menulis cerita pendek (cerpen)/puisi. Kondisi yang ada adalah peserta didik merasa kesulitan mengembangkan idenya dalam menghasilkan sebuah cerpen/puisi. Memang menulis terutama cerpen tidaklah mudah. Hal ini memerlukan latihan secara intens sehingga mereka dapat menghasilkan cerpen yang bagus dan menarik untuk dibaca.

Menulis, apalagi menulis karya sastra, mungkin tidak setiap orang dapat melakukannya. Karena dalam menulis karya sastra, orang harus melakukan kontemplasi sehingga apa yang dihasilkan merupakan pandangan dirinya terhadap suatu keadaan. Peserta didik terkadang 
kesulitan dalam mewujudkan hal tersebut. Hal tersebut menjadi problematika tersendiri bagi pengajar di SMK Negeri 2 Tegal, tempat penelitian ini dilakukan. Peserta didik yang ingin lebih mendalami dalam pembuatan cerpen atau puisi, SMK Negeri 2 Tegal mewadahinya dalam suatu komunitas yang dinamakan Komunitas Baca Tulis (Kobatu). Pengertian komunitas menurut KBBI daring adalah kelompok organisme (orang dan sebagainya) yang hidup dan saling berinteraksi di dalam daerah tertentu; masyarakat; paguyuban. Kobatu adalah komunitas dari sekelompok peserta didik yang bergabung untuk berlatih menulis dan membaca sastra. Dalam komunitas ini, mereka dapat berlatih menulis dan membaca sastra khususnya cerpen dan puisi. Selanjutnya, produk yang mereka ciptakan kemudian dibukukan dalam wujud antologi dan diterbitkan. Selain itu, anggota komunitas juga banyak menjuarai lomba membaca atau menulis cerpen/puisi di tingkat kota. Ada dua hal yang bisa diperoleh dari komunitas ini. Yang pertama, anggota komunitas bertambah ilmu dan demikian mereka semakin berkompeten dalam menulis dan membaca cerpen atau puisi. Yang kedua, timbul rasa percaya diri dalam anggota komunitas karena karya mereka dibukukan dan beberapa di antara mereka menjadi juara dalam hal kepenulisan cerpen.

Di masa pandemi karena virus covid 19, anggota komunitas tidak dapat belajar di sekolah. Waktu mereka kemudian dimanfaatkan untuk berlatih menulis dan membaca di komunitas ini. Dlam komunitas ini lahir karya-karya pada saat orang lain tidak produktif menghasilkan karya karena pandemi covid 19. Komunitas ini sudah ada di saat belum ada pandemi covid 19. Namun, menariknya, komunitas ini semakin produktif pada saat pandemi ini yang ditandai dengan lahirnya beberapa antologi puisi atau cerpen.

Tulisan mengenai kelompok baca tulis ataupun kegiatan literasi pernah ditulis oleh beberapa penulis. Di antaranya adalah Muslimin (2018), yang menulis artikel berjudul "Penumbuhan Budaya Literasi Melalui Peningkatan Minat Baca Masyarakat Desa". Tujuan dari penulisannya adalah: (1) mendeskripsikan secara mendalam penyebab rendahnya minat baca masyarakat khususnya generasi muda usia sekolah; (2) mendiagnosis berbagai penyebab rendahnya minat membaca masyarakat; dan (3) menemukan model kegiatan membaca yang dapat mendorong masyarakat agar mau membaca sehingga terwujud budaya literasi khususnya pada generasi muda usia sekolah di Desa Tabongo Timur, Kecamatan Tabongo, Kabupaten Gorontalo.

Menulis artikel yang berjudul "Literasi Baca Tulis dan Inovasi Kurikulum Bahasa". Tulisan Indriyani dkk bertujuan untuk mengetahui kegiatan literasi yang dilakukan di sekolah dan melihat respon siswa setelah dilaksanakan kegiatan literasi [1].

Tulisan mengenai komunitas baca tulis pernah juga dipaparkan oleh Agusta (2020) dalam artikelnya yang berjudul "Komunitas Baca dalam Menyebar Virus Literasi "Perpustakaan Jalanan DIY". Tulisan Augusta memfokuskan bagaimana aktivitas dari komunitas tersebut berjalan dan mempengaruhi masyarakat dalam peningkatan literasi.

Dalam penelitian ini, ada beberapa tujuan yaitu sebagai berikut.. (1) Mendeskripsikan bagaimana implementasi program kobatu untuk meningkatkan kompetensi peserta didik dalam menulis dan membaca karya sastra. (2) Mendeskripsikan bagaimana hasil dan dampak yang dicapai pasca implementasi program kobatu. (3) Mendekripsikan kendala apa saja yang terjadi pada pengimplementasian program kobatu. (4) Mendeskripsikan faktor apa saja yang mendukung pelaksanaan implementasi program kobatu.

\section{METODOLOGI PENELITIAN}

Metode penelitian yang digunakan meliputi teknik pengumpulan dan analisis data. Teknik pengumpulan data dalam penelian ini menggunakan metode observasi, wawancara, dan kajian pustaka. Observasi dilakukan dengan mengamati kegiatan yang dilakukan para anggota komunitas dan Pembina sekaligus mewawancarai segala hal yang berhubungan dengan kegiatan komunitas. Sedangkan teknik analisis data menggunakan teknik analisis deskriptif kualitatif. Metode analisis deskriptif kualitatif adalah menganalisi, menggambarkan, dan meringkas 
berbagai kondisi, situasi dari berbagai data yang dikumpulkan berupa hasil wawancara atau pengamatan mengenai masalah yang diteliti yang terjadi di lapangan.

\section{HASIL DAN PEMBAHASAN}

Materi pembelajaran karya sastra terkadang menjadi materi yang tidak diminati para peserta didik. Saat pembelajaran karya sastra seperti puisi atau cerpen, terutama saat peserta didik harus unjuk keterampilan, dalam diri peserta didik terkadang sudah muncul rasa "tidak bisa". Hal ini membuat guru harus meyakinkan semua peserta didik, bahwa semua peserta didik mampu unjuk karya asal latihan secara rutin. Kesulitan ini ditambah lagi dengan durasi pembelajaran Bahasa Indonesia di SMK untuk kelas XI dan XII hanya satu kali tatap muka dalam seminggu. Hal ini tidak memungkinkan peserta didik belajar secara intens mengenai karya sastra. Untuk mengantisipasi masalah tersebut, diperlukan pendirian kobatu. Kobatu ini memungkinkan peserta didik secara intens belajar karya sastra. Implementasi kobatu di SMK Negeri 2 antara lain dengan mengadakan latihan-latihan dengan menggunakan berbagai metode. Beberapa metode dan teknik dilakukan, kemudian peserta didik tinggal memilih metode atau teknik apa yang bagi mereka "nyaman" untuk dilakukan.

Kobatu ini sudah menunjukkan, latihan rutin yang mereka lakukan pada akhirnya dapat menghasilkan karya yang bagus, yang dapat ditunjukkan ke dunia luar. Hasil karya komunitas ini selain disimpan di perpustakaan sekolah, juga disimpan di Kantor Arpusda Kota Tegal dan diserahkan kepada Ibu Walikota Tegal selaku Bunda Baca Kota Tegal. Perpusnas RI juga memberikan piagam penghargaan sebagai pengakuan terhadap kobatu di SMK Negeri 2 Tegal.

\section{Langkah-langkah Program Implementasi Kobatu di SMK Negeri 2 Tegal}

Langkah-langkah implementasi kobatu di SMK Negeri 2 Tegal dijabarkan sebagai berikut. Pertama, Perekrutan anggota, dilakukan dengan mengkampanyekan kegiatan kobatu kepada adik-adik kelas. Keanggotaan bersifat terbuka dan suka rela. Yang terpenting mereka harus mempunyai semangat tinggi untuk berkarya.

Kedua, Latihan dan Sharing, dilakukan dengan mengadakan latihan-latihan menggunakan berbagai metode. Beberapa metode dan teknik dilakukan, kemudian peserta didik tinggal memilih metode atau teknik apa yang bagi mereka "nyaman" untuk dilakukan.

Latihan menulis cerpen misalnya menggunakan teknik/metode : Metode Copy the Master, Metode Pembelajaran Berbasis Pengalaman dan Media Audiovisual, dan Teknik Brainwriting. Teknik copy the master dapat diartikan sebagai model untuk ditiru. Model tidak hanya terbatas pada peniruan lateral, namun ada tahap perbaikan. Tahap peniruan sampai dengan perbaikan inilah yang menonjol dalam strategi ini. Strategi ini menuntut dilakukan latihan-latihan sesuai dengan model yang ditawarkan. siswa mendapat pengalaman langsung karena mendapat kesempatan mengamati atau mencermati model tulisan, sehingga pemahaman siswa tentang konsep lebih konkret [2].

Media audio visual adalah media yang memiliki unsur suara dan unsur gambar. Media ini mempunyai kemampuan yang lebih baik karena meliputi dua media yaitu media auditif (mendengar) dan visual (melihat) [3]. Media ini merupakan alat bantu yang dapat dipergunakan untuk membantu siswa dalam menularkan pengetahuan, ide ke dalam bentuk tulisan. Media ini juga merupakan media yang termurah dan terjangkau.

Brainwriting adalah bentuk alternatif dari brainstorming, suatu teknik kreatif yang diterapkan dalam kelompok [4]. Tujuannya supaya anggota dalam kelompok dapat bertukar pikiran. Anggota kelompok dituntut untuk berbagi ide dan mengembangkan ide-ide secara tertulis. Metode ini dapat menjadi alternatif supaya siswa lebih berpartisipasi secara seragam dalam suatu kelompok. Seperti halnya brainstorming, brainwriting dirancang untuk menghasilkan banyak ide dalam waktu singkat.

Latihan membaca cerpen misalnya menggunakan teknik/metode: teknik membaca kritis, Metode SQ3R, Metode P2R, dan Metode berpikir-berpasangan-berbagi. Teknik 5W+1H efektif dalam menemukan unsur intrinsik cerpen yaitu dengan cara membaca kritis cerpen tersebut. 
Keunggulan teknik $5 \mathrm{~W}+1 \mathrm{H}$ yaitu mempermudah siswa mencari unsur-unsur intrinsik cerpen, dengan memilah-milah unsur atau membuat pertanyaan sendiri terkait dengan teknik $5 \mathrm{~W}+1 \mathrm{H}$. Hal ini akan membuat siswa dengan mudah memahami cerpen yang dibacanya. Teknik $5 \mathrm{~W}+1 \mathrm{H}$ juga mendorong siswa untuk berpikir dan bekerja atas inisiatif sendiri. Siswa lebih mandiri, aktif dan kritis dalam mengikuti proses belajar [5].

SQ3R merupakan metode belajar yang menuntut siswa untuk aktif dalam hal menyurvei atau menyelidiki, bertanya, membaca, memperkokoh perolehan dalam membaca, dan mengulangi pemahaman diri sendiri [6]. Metode ini meliputi beberapa unsur yaitu, S (Survey) yaitu menyelidiki, Q (Question), yaitu bertanya, R (Read), yaitu membaca, R( Recite), yaitu memperkokoh pemerolehan membaca, dan R (Review), yaitu mengulangi.

Metode P2R menurut Sutardi dan Sudirjo merupakan salah satu cara yang digunakan untuk meneliti siswa dalam membaca cerpen dengan model berpikir-berrpasangan-berbagi. Sementara berpikir-berpasangan-berbagi adalah jenis model pembelajaran kooperatif yang menggunakan kelompok-kelompok kecil. Siswa saling bekerja sama dan membantu satu sama lain dalam menyelesaikan tugas yang dipelajarinya [7].

Latihan menulis puisi misalnya menggunakan metode/teknik: pendekatan kontekstual, media audio visual, metode partisipatori, dan media gambar. Pendekatan kontekstual adalah suatu pendekatan yang menghubungkan materi yang diajarkan dengan situasi dunia nyata siswa. Hal tersebut dapat menolong siswa melihat makna di dalam materi akademik dengan cara menghubungkan subjek-subjek akademik dengan konteks kehidupan keseharian mereka, yaitu konteks keadaan pribadi, sosial, dan budaya [8].

Teknik menulis puisi lainnya adalah dengan menggunakan media audio visual seperti yang sudah diterangkan di atas.

Teknik menulis puisi juga dapat menggunakan metode partisipatori Metode partisipatori adalah adalah metode pembelajaran dengan menekankan keterlibatan siswa secara penuh. Metode ini dilakukan di dalam kelas dengan bantuan media gambar dan pengalaman. Siswa dianggap sebagai penentu keberhasilan belajar. Dengan berpartisipasi aktif, siswa dapat menemukan hasil belajar. Guru hanya bersifat sebagai pemandu atau fasilitator [9]. Pengertian media gambar menurut KBBI adalah alat dan bahan yang digunakan dalam proses pengajaran atau pembelajaran yang berupa tiruan barang (orang, binatang, tumbuhan) yang dibuat dalam coretan pensil pada kertas dan lukisan.

Latihan membaca puisi dengan menggunakan teknik/metode:Teknik pemodelan dan Metode cooperative script. Teknik Pemodelan merupakan teknik dengan pemberian pengalaman belajar berupa peragaan secara langsung, yang akan membantu pemahaman siswa dalam pelafalan, penghayatan, dan penampilan sesuai dengan puisi yang dibacakan [10].

Mengenai Coorperative script, Mursitho menjelaskan bahwa cooperative script adalah metode belajar yang melatih peserta didik untuk bekerja sama, menghargai pendapat orang lain (pasangannya), belajar mendengarkan, dan belajar berbicara secara sistematis. Pada metode ini, siswa akan dikelompokan berpasangan dengan temannya. Siswa berperan sebagai pembicara dan pendengar. Pembicara membuat ringkasan dari teks bacaan, kemudian disampaikan kepada pendengar dan pendengar akan menyimak atau mengoreksi apa yang disampaikan oleh pembicara [11].

Latihan yang dilakukan bersifat intens dan sharing. Anggota komunitas saling berbagi pengalaman di dalam menulis karya.

Ketiga, Launching Produk. Launching produk dilakukan ketika produk dari komunitas ini yang berupa antologi cerpen atau puisi sudah jadi. Kegiatan launching ini diadakan suatu perayaan, misalnya dengan lomba-lomba atau pementasan puisi. Juga untuk lebih mengenalkan produk komunitas baca SMK Negeri 2, antologi diserahkan juga kepada Kantor Cabang Dinas Pendidikan Wilayah XI, Kantor Arpusda Kota Tegal, dan Bunda Baca Kota Tegal yaitu Ibu Walikota Tegal.

\section{Hasil Implementasi Program Kobatu di SMK Negeri 2 Tegal}


Implementasi program konunitas baca tulis di SMK Negeri 2 Tegal menunujukkan hasil yang signifikan. Hasilnya antara lain sebagai berikut. (1) Terbitnya antologi puisi dan cerpen sebagai perwujudan hasil pelatihan yang dilakukan. (2) Peserta didik yang tergabung sebagai anggota komunitas semakin meningkat kompetensinya. Hal ini dibuktikan dengan karya mereka yang dibukukan. (3) Beberapa anggota komunitas menjadi juara dalam lomba cipta cerpen yang diadakan di Kantor Arpusda Kota Tegal. (4) Timbulnya rasa percaya diri pada anggota komunitas bahwa mereka dapat mencipta sastra. (5) Kobatu menjadi program unggulan sekolah yang dapat dibanggakan. (6) Keberadaan Kobatu SMK Negeri 2 Tegal diakui oleh Perpusnas RI.

\section{Kendala dalam Pelaksanaan Program Kobatu di SMK Negeri 2 Tegal}

Dalam implementasinya, kobatu tidak mengalami kendala berarti. Namun demikian, kendala pasti tetap ada. Kendala yang ada dijabarkan sebagai berikut. Pertama, Waktu latihan yang terbatas. Menulis karya sastra memerlukan waktu latihan yang berulang-ulang. Keterbatasan waktu menyebabkan peserta didik terhambat di dalam menyelesaikan suatu karya. Namun, semangat yang tinggi dari mereka membuat mereka berhasil membuat sebuah karya di sela-sela padatnya tugas sekolah.

Kedua, Pemahaman Peserta didik. Setiap anak dilahirkan dengan keistimewaan sendirisendiri. Termasuk dalam hal pemahaman, setiap peserta didik tentu berbeda. Namun demikian, hal tersebut dapat diatasi dengan ketelatenan para pembina komunitas.

Kobatu di SMK Negeri 2 Tegal dapat eksis karena adanya faktor pendukung. Faktorfaktor pendukung dalam implementasi kobatu antara lain sebagai berikut. Pertama, Pihak sekolah. Pihak sekolah sangat mendukung sekali adanya kobatu ini. Sekolah memfasilitasi mulai dari tempat kegiatan, latihan, mengundang narasumber, menyediakan saraana-prasarana, sampai perayaan launching buku atau antologi.

Ketiga, Guru. Guru-guru juga mendukung adanya kobatu. Mereka ikut membina kegiatan yang dilaksanakan oleh kobatu.

Keempat, Peserta didik. Semangat peserta didik dalam komunitas ini menjadi modal utama adanya kobatu. Tanpa adanya semangat, sebuah karya tidak akan terwujud.

\section{SIMPULAN}

Simpulan dalanm penelitian ini adalah sebagai berikut. (1) Implementasi program kobatu untuk meningkatkan kompetensi peserta didik dalam menulis dan membaca karya sastra antara lain dengan perekrutan anggota; latihan atau sharing, dan launching produk. (2) Hasil dan dampak yang dicapai pasca implementasi program kobatu antara lain: peserta didik yang tergabung dalam anggota komunitas semakin meningkat kompetensinya dalam mencipta karya sastra yang diwujudkan dalam produk berupa antologi; peserta didik lebih percaya diri; dan Kobatu dapat menjadi program unggulan sekolah dan diakui secara resmi oleh Perpusnas RI. (3) Kendala yang terjadi pada pengimplementasian program kobatu antara lain masalah waktu latihan yang terbatas dan pemahaman peserta didik yang tidak sama. (4) Faktor yang mendukung pelaksanaan implementasi program kobatu antara lain dari pihak sekolah; peserta didik; dan guru.

\section{REFERENCES}

[1] Indriyani, V., Zaim, M., Atmazaki, dan Ramadhan, S. (2019). "Literasi Baca Tulis dan Inovasi Kurikulum Bahasa". Jurnal Kembara, 5(1), hlm.108-118.

[2] Kurnianingtyas, E. (2015). "Penerapan Teknik Copy the Master untuk Meningkatkan Keterampilan Menulis Cerpen Siswa Kelas VII-B MTS Darun Najah Petahunan Lumajang”. Jurnal Nosi, 2(8), hlm. 30- 40.

[3] Mulyati, N.S. (2017). Peningkatan Kemampuan Menulis Puisi Bebas Menggunakan Media Audio Visual”. E-Jurnal Literasi, 1(1), hlm. 18-27. 
[4] Nurhayati, N. (2015). "Model Pembelajaran Menulis Cerita Pendek dengan Menggunakan Teknik Brainwriting yang Berorientasi pada Kreativitas Siswa". Jurnal Riksa Bahasa, 1(1), hlm.14-26.

[5] Aryanta, K.A., Wendra, W., dan Artawan, I.G. (2012). "Penggunaan Teknik $5 \mathrm{~W}+1 \mathrm{H}$ untuk Meningkatkan Kemampuan Memahami Unsur Intrinsik Cerpen melalui Membaca Kritis di Kelas VII C SMP Negeri 3 Singaraja". Jurnal Pendidikan Bahasa Indonesia Undiksha, 2(1), hlm. 1-1.

[6] Aisyaturradiah, Nurjaya, I.G., dan Astika, I.M. (2014) "Penerapan Metode SQ3R Berbantuan Media Cerpen untuk Meningkatkan Kemampuan Membaca Pemahaman Siswa Kelas XI IPS SMA Negeri Gerokgak”, Jurnal Pendidikan Bahasa dan Sasstra Indonesia Undiksha, 2(1), hlm.1-12.

[7] Berti, Arti, (2019). "Peningkatan Keterampilan Membaca Cerpen dengan menggunakan Metode P2R dan Berpikir-Berpesangan-Berbagi”. Jurnal Pendidikan Tambusai, 3(6), hlm.1234-1242.

[8] Budiastuti, W., Mulyono, S., dan Hastuti, S. (2014). "Peningkatan Motivasi dan Keterampilan Menulis puisi dengan Penerapan Pendekatan Kontekstual pada Siswa Sekolah Dasar". Jurnal Basastra, 1(3), hlm. 573-582.

[9] Laeli A.N., Wagiran, dan Suseno. (2014). "Peningkatan Keterampilan Menulis Puisi Keindahan Alam Menggunakan Metode Partisipatori dengan Media Gambar”. Jurnal Pendidikan Bahasa dan Sastra Indonesia, 3(1), hlm. 1-7.

[10] Binol, Y.M., Karim, A., dan Efendi. 2017. "Peningkatan Kemampuan Membaca Puisi Melalui Teknik Pemodelan Siswa Kelas IV SDN 05 Bunobogu". Jurnal Kreatif Tadulako Online, 5(4), hlm.68-84.

[11] Laguliga, S.A., Lembah, G., Nur, Y. (2017). "Upaya Peningkatan Keterampilan Membaca Puisi pada Siswa Kelas X SMA Negeri 7 Sigi melalui Metode Cooperative Script". Jurnal Bahasantondea, 5(3), hlm. 80-86. 